\title{
Renal Tubular Transport of Proline, Hydroxyproline, and Glycine. II. Hydroxy-L-proline as Substrate and as Inhibitor In Vivo*
}

\author{
C. R. SCRIVER † ANd H. Goldman \\ (From the DeBelle Laboratory for Biochemical Genetics, The Montreal Children's Hospital, \\ and the Department of Pediatrics, McGill University, Montreal, Quebec, Canada)
}

Renal tubular absorption of the free amino acids L-proline, hydroxy-L-proline, and glycine in man is accomplished by a transport system exhibiting preference for this group of amino acids $(1,2)$. The characteristics of saturability (for L-proline transport) and selective inhibition between the constituent substrates have been demonstrated for this system in man (1). Studies in vivo in the rat $(3,4)$ also reveal a transport system in that animal with preference for the same three amino acids. Studies in vitro with rat kidney cortex slices (4) and other tissues $(5,6)$ confirm this finding and also indicate that, within the system showing group preference, there may be discrete catalytic transport sites for the individual substrates $(4,6)$. The apparent order of substrate affinities for the transport system or systems is highest for L-proline and lowest for glycine $(1,4)$.

A maximal rate for renal tubular absorption of L-proline ( $\mathrm{Tm}$ Pro) has been shown in man (1). In the present work the behavior of free hydroxyL-proline as substrate and its effect as an inhibitor within the system were studied. A Tm for hydroxyproline (Tm Hypro) was demonstrated; the imino acid was also shown to be a poor inhibitor of L-proline transport but more effective against glycine.

\footnotetext{
* Submitted for publication November 8, 1965; accepted May 20, 1966.

Supported by grant AM-05117-04 from the Division of Metabolism and Arthritis, National Institutes of Health; and grant MA-1894 from the Medical Research Council of Canada.

Part I reported renal tubular transport of L-proline (1).

† Markle Scholar in Medical Sciences.

Address requests for reprints to Dr. Charles R. Scriver, the Montreal Children's Hospital, 2300 Tupper St., Montreal 25, Quebec, Canada.
}

\section{Methods}

Subjects

Four healthy adult Caucasian males between 30 and 39 years of age were studied. Two subjects (2 and 3 ) were given two infusions; the remaining two were given one infusion.

\section{Techniques}

Infusions were performed in the morning with the subjects in the resting state after an overnight fast. Sufficient water was given by mouth to ensure a diuresis exceeding $5 \mathrm{ml}$ per minute. Urine was collected by spontaneous voiding while subjects were standing. The steady state infusion technique used in these experiments has been described previously (1). Hydroxy-L-proline was given in priming doses of 0.4 to 1.2 mmoles per $\mathrm{kg}$ ( 50 to $150 \mathrm{mg}$ per $\mathrm{kg}$ ) ; the sustaining dose was $3.5 \mu$ moles per $\mathrm{kg}$ per minute.

Infusion of free hydroxy-L-proline is followed about 12 hours later by muscular ache, mild pyrexia, and nausea. These sensations disappear within 24 hours. This response is dose dependent, and the two subjects who were given two infusions felt greater discomfort with the larger infusion. Hydroxyprolinuria or persistence of hydroxyprolinemia were not observed at the time of symptoms. The origin of this reaction remains obscure.

\section{Materials}

Hydroxy-L-proline (chromatographically pure) was obtained commercially. ${ }^{1}$ Purity was confirmed by chromatographic analysis in $n$-butanol, acetic acid, water $(12: 3: 5)$ followed by staining with Ninhydrin $(0.2 \%$ in acetone) and sequential staining with isatin $(0.2 \%$ in acetone) followed by Ehrlich's reagent (7).

\section{Preparation of samples}

All urine samples were preserved with thymol and stored immediately after collection at $-20^{\circ} \mathrm{C}$. Plasma was separated from heparinized whole venous blood by centrifugation within an hour after collection. A sample of plasma was immediately added to $0.437 \mathrm{~N}$ picric acid (plasma: picric acid; $1: 5$ ), and after precipitation of the protein, the picric acid was removed on Dowex $2 \times 8$ resin $\left(\mathrm{Cl}^{-}\right)(8)$. The reconstituted sample was stored at $-20^{\circ}$ $\mathrm{C}$ until analysis.

\footnotetext{
1 Mann Research Laboratories, New York, N. Y.
} 


\section{Analytical methods}

Qualitative. The amino acid content of 2-second volumes of urine was examined by ascending partition chromatography in two dimensions in water-saturated phenol followed by 2,6 -lutidine, water $(2.2: 1)$. Plasma (10 $\mu 1)$ was chromatographed in one dimension without deproteinization in $n$-butanol, acetic acid, and water $(12: 3: 5)$, and the amino acids were identified with a Ninhydrinisatin mixture plus sequential staining techniques to demonstrate hydroxyproline specifically (9).

Quantitative. Analysis of amino acids in appropriate urine volumes (2- to 10 -second volumes) and plasma $(0.415 \mathrm{ml})$ was performed on ion exchange resins according to the techniques of Spackman, Moore, and Stein (8) using a Beckman-Spinco amino acid analyzer (model 120) equipped with 6-mm light path cuvettes in the colorimeter. Inulin in urine and plasma was determined by the method of Schreiner (10).
Net tubular absorption of amino acids (AA) was calculated from the formula $\left[\mathrm{C}_{\text {In }}\right.$ (milliliters per minute) $\times$ plasma $_{\mathbf{A A}}$ (micromoles per milliliter)] - urine $\mathbf{A A}$ (micromoles per minute) $=$ absorbed (micromoles per minute), where $C_{I n}=$ inulin clearance. The venous plasma threshold for hydroxyprolinuria was calculated by the "linemethod," according to Smith (11).

\section{Results}

Hydroxy-L-proline Tm. Tubular absorption of the small amounts $(0.01 \mu$ mole per $\mathrm{ml})$ of free hydroxyproline present in fasting plasma is normally complete (Table I). Hydroxyprolinuria was not detected until the filtered load had been greatly increased (Tab!e I). The venous plasma threshold for linear urinary excretion of hydroxy-

TABLE I

Tubular absorption of free hydroxy-L-proline in relation to filtered load

\begin{tabular}{|c|c|c|c|c|c|c|c|c|c|}
\hline & Subject & Period & Time & $\begin{array}{l}\text { Inulin } \\
\text { clearance }\end{array}$ & $\begin{array}{l}\text { Plasma } \\
\text { Hypro* }\end{array}$ & $\begin{array}{l}\text { Filtered } \\
\text { Hypro }\end{array}$ & $\begin{array}{l}\text { Excreted } \\
\text { Hypro }\end{array}$ & \multicolumn{2}{|c|}{$\begin{array}{c}\text { Tubular absorption } \\
\text { Hypro }\end{array}$} \\
\hline \multirow{8}{*}{ 1) } & & & $\min$ & $m l / m i n$ & umoles $/ \mathrm{ml}$ & umales/min & umoles/min & $\mu$ moles $/ \mathrm{min}$ & $\begin{array}{l}\% \text { filtered } \\
\text { load }\end{array}$ \\
\hline & Male, aged & Control & $46-65$ & 112 & $\sim 0.01$ & & 0 & & 100.0 \\
\hline & 34 years; weight, & $1 \mathrm{~A}$ & $95-105$ & 118 & 0.82 & 96.3 & 37.0 & 59.3 & 62.0 \\
\hline & $70 \mathrm{~kg}$. & $1 \mathrm{~B}$ & $105-122$ & 133 & 0.67 & 88.9 & 41.6 & 47.3 & 53.0 \\
\hline & Priming & $2 \mathrm{~A}$ & $156-175$ & 120 & 1.23 & 147.6 & 68.0 & 79.6 & 53.0 \\
\hline & doses, & $2 \mathrm{~B}$ & $175-190$ & 120 & 1.03 & 123.6 & 68.0 & 55.6 & 45.0 \\
\hline & $100 \mathrm{mg} / \mathrm{kg}$ & $3 \mathrm{~A}$ & $222-238$ & 104 & 2.52 & 262.1 & 193.2 & 69.9 & 26.0 \\
\hline & & $3 \mathrm{~B}$ & $238-254$ & 102 & 1.95 & 199.2 & 152.4 & 46.8 & 23.0 \\
\hline \multirow{10}{*}{ 2) } & Male, aged & & & & & & & & \\
\hline & 35 years; weight, & Control & $30-80$ & 135 & $\sim 0.01$ & & 0 & & 100.0 \\
\hline & a) Prime, & $1 \mathrm{~A}$ & $115-133$ & $\begin{array}{l}153 \\
140\end{array}$ & 0.24 & 33.6 & 2.0 & 31.6 & 94.0 \\
\hline & $50 \mathrm{mg} / \mathrm{kg}$. & $3 \mathrm{~A}$ & $238-254$ & 105 & 0.54 & 56.5 & 4.2 & 52.3 & 92.5 \\
\hline & b) Prime, & $1 \mathrm{~A}$ & $45-60$ & 140 & 0.42 & 58.7 & 2.1 & 56.6 & 96.4 \\
\hline & $75 \mathrm{mg} / \mathrm{kg}$ & $1 \mathrm{~B}$ & $60-76$ & 145 & 0.46 & 66.6 & 0.9 & 65.6 & 98.4 \\
\hline & Prime, & $2 \mathrm{~A}$ & $121-136$ & 125 & 1.04 & 130.0 & 10.9 & 119.1 & 91.6 \\
\hline & $75 \mathrm{mg} / \mathrm{kg}$. & $2 \mathrm{~B}$ & $136-151$ & 122 & 0.78 & 96.6 & 7.8 & 88.2 & 91.8 \\
\hline & Prime, & $3 \mathrm{~A}$ & $197-213$ & 130 & 1.43 & 186.0 & 47.0 & 139.0 & 74.7 \\
\hline & $100 \mathrm{mg} / \mathrm{kg}$ & $3 \mathrm{~B}$ & $213-229$ & 136 & 1.28 & 168.2 & 35.0 & 132.4 & 78.7 \\
\hline \multirow{11}{*}{ 3) } & Male, aged & $1 \mathrm{~A}$ & $40-57$ & 125 & 0.35 & 43.7 & 16.7 & 27.0 & 61.8 \\
\hline & 39 years; weight, & $1 \mathrm{~B}$ & $57-73$ & 142 & 0.35 & 49.7 & 6.2 & 43.5 & 87.5 \\
\hline & $75 \mathrm{~kg}$. & $2 \mathrm{~B}$ & $114-130$ & 130 & 0.65 & 84.5 & 16.2 & 68.3 & 80.8 \\
\hline & a) Prime, & $3 \mathrm{~A}$ & $161-176$ & 137 & 0.94 & 128.8 & 37.6 & 91.2 & 70.9 \\
\hline & $75 \mathrm{mg} / \mathrm{kg}$ & $3 \mathrm{~B}$ & $176-193$ & 130 & 0.87 & 113.1 & 19.6 & 93.5 & 82.6 \\
\hline & b) Prime, & $1 \mathrm{~A}$ & $45-75$ & 94 & 0.61 & 57.4 & 18.6 & 36.8 & 62.6 \\
\hline & $100 \mathrm{mg} / \mathrm{kg}$ & $1 \mathrm{~B}$ & $75-92$ & 100 & 0.50 & 50.0 & 15.5 & 35.5 & 71.0 \\
\hline & & $2 \mathrm{~A}$ & $142-159$ & 150 & 0.94 & 142.0 & 71.7 & 71.3 & 50.0 \\
\hline & & $2 \mathrm{~B}$ & $159-166$ & 128 & 0.78 & 99.8 & 35.2 & 64.6 & 64.7 \\
\hline & & $3 \mathrm{~A}$ & $211-227$ & 116 & 1.40 & 162.0 & 85.0 & 77.0 & 48.7 \\
\hline & & $3 \mathrm{~B}$ & $227-244$ & 110 & 1.40 & 154.0 & 70.0 & 84.0 & 54.7 \\
\hline \multirow{6}{*}{ 4) } & Male, aged & $1 \mathrm{~A}$ & $40-58$ & 154 & 0.64 & 97.8 & 9.0 & 88.8 & 90.8 \\
\hline & 30 years; weight, & $1 \mathrm{~B}$ & $58-75$ & 142 & 0.81 & 115.5 & 6.2 & 109.3 & 94.6 \\
\hline & $75 \mathrm{~kg}$. & $2 \mathrm{~A}$ & $120-136$ & 141 & 0.94 & 132.5 & 22.6 & 109.9 & 82.9 \\
\hline & Prime, & $2 B$ & $136-151$ & 158 & 0.89 & 140.9 & 15.4 & 125.5 & 89.1 \\
\hline & $75 \mathrm{mg} / \mathrm{kg}$ & $3 \mathrm{~A}$ & $192-207$ & 132 & 1.31 & 172.2 & 37.6 & 134.6 & 78.1 \\
\hline & & $3 \mathrm{~B}$ & $207-225$ & 119 & 1.29 & 153.6 & 29.1 & 124.5 & 81.1 \\
\hline
\end{tabular}

\footnotetext{
* Hypro = hydroxyproline.
} 
TABLE II

Maximal tubular absorption of hydroxy-L-proline in man

\begin{tabular}{|c|c|c|c|c|c|c|}
\hline Subject & $\begin{array}{l}\text { Average } \\
\text { inulin } \\
\text { clearance } \\
\text { at } \mathrm{Tm}\end{array}$ & $\begin{array}{c}\text { Maximal } \\
\text { plasma } \\
\text { Hypro } \\
\text { concen- } \\
\text { tration } \\
\text { reached }\end{array}$ & $\begin{array}{c}\text { Venous } \\
\text { plasma } \\
\text { threshold } \\
\text { for Hypro }\end{array}$ & $\begin{array}{l}\text { Maximal } \\
\text { rate of } \\
\text { tubular } \\
\text { absorption } \\
(\mathrm{Tm})\end{array}$ & $\frac{C_{\text {Hypro }}}{C_{\text {In }}}$ & 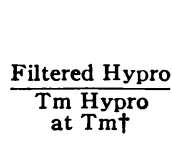 \\
\hline & $m l / \min$ & $\mu$ moles $/ m l$ & $\mu$ moles $/ \mathrm{ml}$ & umoles/min & & \\
\hline $\begin{array}{l}1 \\
2 \\
3 \ddagger \\
4\end{array}$ & $\begin{array}{l}110 \\
130 \\
118 \\
136\end{array}$ & $\begin{array}{l}2.52 \\
1.43 \\
1.40 \\
1.31\end{array}$ & $\begin{array}{l}0.4 \\
0.7 \\
0.4 \\
0.7\end{array}$ & $\begin{array}{r}60 \\
135 \\
80 \\
125\end{array}$ & $\begin{array}{l}0.71 \\
0.26 \\
0.44 \\
0.17\end{array}$ & $\begin{array}{l}4.4 \\
1.4 \\
2.0 \\
1.4\end{array}$ \\
\hline
\end{tabular}

* $\mathrm{C}=$ clearance In $=$ inulin.

t Calculated at maximal filtered load achieved.

$\ddagger$ Average of two infusions.

proline in these experiments was above $0.4 \mu$ mole per $\mathrm{ml}$ (Table II). Tubular absorption of hydroxyproline increases steadily as the filtered load increases, whereas fractional absorption of the filtered load decreases. In two subjects (1 and 3 ) a maximal rate of absorption was achieved (Figure 1). One of those subjects (3) was given two infusions, 8 months apart; the rates of hydroxyproline absorption in the two experiments were reasonably comparable (Figure 1). A Tm Hypro was probably achieved also in the other two subjects, although unequivocal evidence could not be obtained. $^{2}$ If we assume that a maximal rate for hydroxyproline absorption was actually reached in each subject (Table II), the filtered and absorbed loads were then evaluated in relation to the appro-

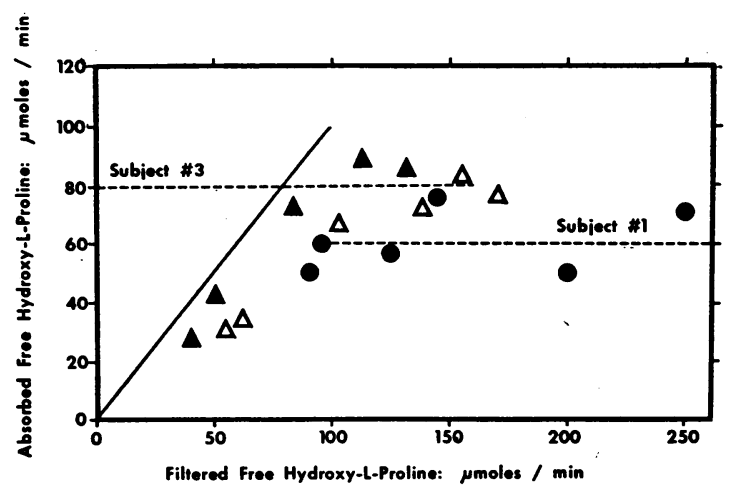

Fig. 1. TUBULAR ABSORPTION OF FREE HYDROXYPROLINE PLOTTED AS A FUNCTION OF THE FILTERED SUBSTRATE LOAD DURING THREE INFUSIONS IN TWO SUBJECTS. Solid and open triangles represent experiments $3 a$ and $b$, respectively. Solid circles refer to Subject 1. Data were taken from Table I.

\footnotetext{
${ }^{2}$ Subject 2 was infused twice; the first infusion was inadequate, and only two representative periods are presented in Table I and Figure 2.
}

priate $T m$ for 31 different substrate concentrations from all the experiments. With the absorption rate plotted against the substrate load, a typical progression from first-order to zero-order kinetics was found (Figure 2).

Hydroxy-L-proline as inhibitor. High concentrations of free hydroxy-L-proline in tubular urine have an inhibitory effect upon the transport of glycine and proline (Tables III and IV). [The inhibition has been shown to be competitive (4).] Tubular absorption of other amino acids was not significantly impaired. The inhibitory effect of hydroxyproline was greater on glycine transport than on L-proline transport (Figure 3 ) when the filtered loads of the two substrates were comparable. Inspection of Tables III and IV reveals that more hydroxyproline is required to displace proline than is required to inhibit glycine transport to a similar degree. The two subjects with the lower

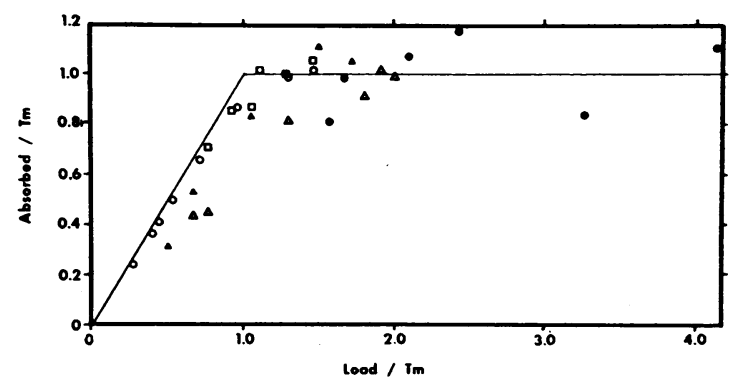

Fig. 2. SUMMARY OF HYDROXYPROLINE ABSORPTION AS A FUNCTION OF SUBSTRATE LOAD PLOTTED IN THE MANNER of Smith (11). Progression from first-order to zeroorder kinetics in a saturable transport system is suggested by the distribution of 31 observations. (Solid line represents theoretical plot only.) Experiments 1, 2, 3a, $3 \mathrm{~b}$, and 4 are represented by solid circles, open circles, solid and open triangles, and open squares, respectively. $\mathrm{T} \mathrm{m}=$ maximal absorption. 
TABLE III

Inhibition of tubular transport of glycine by hydroxy-L-proline in man

\begin{tabular}{|c|c|c|c|c|c|c|c|}
\hline \multirow{3}{*}{ Subject } & \multirow{3}{*}{ Period } & \multirow{3}{*}{$\begin{array}{c}\begin{array}{c}\text { Hypro } \\
\text { filtered }\end{array} \\
\text { mmoles/min }\end{array}$} & \multicolumn{5}{|c|}{ Glycine } \\
\hline & & & \multirow{2}{*}{$\begin{array}{c}\text { Plasma } \\
\mu m o l e / m l\end{array}$} & \multirow{2}{*}{$\frac{\text { Filtered }}{\mu \text { moles } / \text { min }}$} & \multirow{2}{*}{$\begin{array}{c}\text { Excreted } \\
\text { umoles/min }\end{array}$} & \multicolumn{2}{|c|}{ Tubular absorption } \\
\hline & & & & & & umoles/min & $\begin{array}{c}\text { \% fillered } \\
\text { load }\end{array}$ \\
\hline 1 & $\begin{array}{c}\text { Control } \\
1 \mathrm{~A} \\
1 \mathrm{~B} \\
2 \mathrm{~A} \\
2 \mathrm{~B} \\
3 \mathrm{~A} \\
3 \mathrm{~B}\end{array}$ & $\begin{array}{r}\text { Trace } \\
96.3 \\
88.9 \\
147.6 \\
123.6 \\
262.1 \\
199.2\end{array}$ & $\begin{array}{l}0.24 \\
0.28 \\
0.26 \\
0.29 \\
0.28 \\
0.32 \\
0.30\end{array}$ & $\begin{array}{l}26.9 \\
33.0 \\
34.6 \\
34.8 \\
33.6 \\
33.3 \\
30.6\end{array}$ & $\begin{array}{r}1.5 \\
4.3 \\
4.3 \\
9.5 \\
4.3 \\
13.6 \\
6.8\end{array}$ & $\begin{array}{l}25.4 \\
28.7 \\
30.3 \\
25.3 \\
29.3 \\
22.7 \\
23.6\end{array}$ & $\begin{array}{l}94.4 \\
86.9 \\
87.5 \\
72.7 \\
87.2 \\
68.2 \\
77.1\end{array}$ \\
\hline 2 a) & $\begin{array}{c}\text { Control } \\
1 \mathrm{~A} \\
3 \mathrm{~A}\end{array}$ & $\begin{array}{r}\text { Trace } \\
33.6 \\
56.5\end{array}$ & $\begin{array}{l}0.20 \\
0.20 \\
0.18\end{array}$ & $\begin{array}{l}27.0 \\
28.0 \\
18.9\end{array}$ & $\begin{array}{l}1.1 \\
2.6 \\
2.7\end{array}$ & $\begin{array}{l}25.9 \\
25.4 \\
16.2\end{array}$ & $\begin{array}{l}95.9 \\
90.7 \\
85.7\end{array}$ \\
\hline b) & $\begin{array}{l}1 \mathrm{~A} \\
1 \mathrm{~B} \\
2 \mathrm{~A} \\
2 \mathrm{~B} \\
3 \mathrm{~A} \\
3 \mathrm{~B}\end{array}$ & $\begin{array}{r}58.7 \\
66.6 \\
130.0 \\
96.0 \\
186.0 \\
168.2\end{array}$ & $\begin{array}{l}0.18 \\
0.22 \\
0.23 \\
0.21 \\
0.22 \\
0.22\end{array}$ & $\begin{array}{l}25.2 \\
31.9 \\
28.7 \\
25.6 \\
28.6 \\
29.9\end{array}$ & $\begin{array}{l}3.2 \\
3.6 \\
4.0 \\
3.4 \\
4.4 \\
4.2\end{array}$ & $\begin{array}{l}22.0 \\
28.3 \\
24.7 \\
22.4 \\
24.2 \\
25.7\end{array}$ & $\begin{array}{l}87.3 \\
88.7 \\
86.0 \\
87.5 \\
84.6 \\
85.9\end{array}$ \\
\hline 3 a) & $\begin{array}{l}1 \mathrm{~B} \\
2 \mathrm{~B} \\
3 \mathrm{~A} \\
3 \mathrm{~B}\end{array}$ & $\begin{array}{r}49.7 \\
84.5 \\
128.8 \\
113.1\end{array}$ & $\begin{array}{l}0.14 \\
0.17 \\
0.20 \\
0.18\end{array}$ & $\begin{array}{l}19.8 \\
22.1 \\
27.4 \\
23.4\end{array}$ & $\begin{array}{l}2.3 \\
2.8 \\
4.6 \\
3.0\end{array}$ & $\begin{array}{l}17.5 \\
19.3 \\
22.8 \\
20.4\end{array}$ & $\begin{array}{l}88.4 \\
87.3 \\
83.2 \\
87.1\end{array}$ \\
\hline b) & $\begin{array}{l}2 \mathrm{~A} \\
2 \mathrm{~B} \\
3 \mathrm{~A} \\
3 \mathrm{~B}\end{array}$ & $\begin{array}{r}142.0 \\
99.8 \\
162.0 \\
154.0\end{array}$ & $\begin{array}{l}0.19 \\
0.18 \\
0.17 \\
0.21\end{array}$ & $\begin{array}{l}28.5 \\
23.0 \\
19.7 \\
23.2\end{array}$ & $\begin{array}{l}6.7 \\
5.5 \\
5.6 \\
6.6\end{array}$ & $\begin{array}{l}21.8 \\
17.5 \\
14.1 \\
16.6\end{array}$ & $\begin{array}{l}76.8 \\
76.0 \\
71.2 \\
71.1\end{array}$ \\
\hline 4 & $\begin{array}{l}1 \mathrm{~A} \\
1 \mathrm{~B} \\
2 \mathrm{~A} \\
2 \mathrm{~B} \\
3 \mathrm{~A} \\
3 \mathrm{~B}\end{array}$ & $\begin{array}{r}97.8 \\
115.5 \\
132.5 \\
140.9 \\
172.2 \\
153.6\end{array}$ & $\begin{array}{l}0.19 \\
0.25 \\
0.21 \\
0.21 \\
0.23 \\
0.24\end{array}$ & $\begin{array}{l}29.9 \\
35.9 \\
29.5 \\
33.6 \\
30.7 \\
28.5\end{array}$ & $\begin{array}{l}3.7 \\
3.5 \\
4.7 \\
4.3 \\
5.0 \\
4.6\end{array}$ & $\begin{array}{l}26.1 \\
32.4 \\
24.8 \\
29.3 \\
25.6 \\
23.9\end{array}$ & $\begin{array}{l}87.4 \\
90.3 \\
84.0 \\
87.2 \\
83.6 \\
83.9\end{array}$ \\
\hline
\end{tabular}

maximal rate of hydroxyproline transport (Subjects 1 and 3, Table II) showed a tendency for

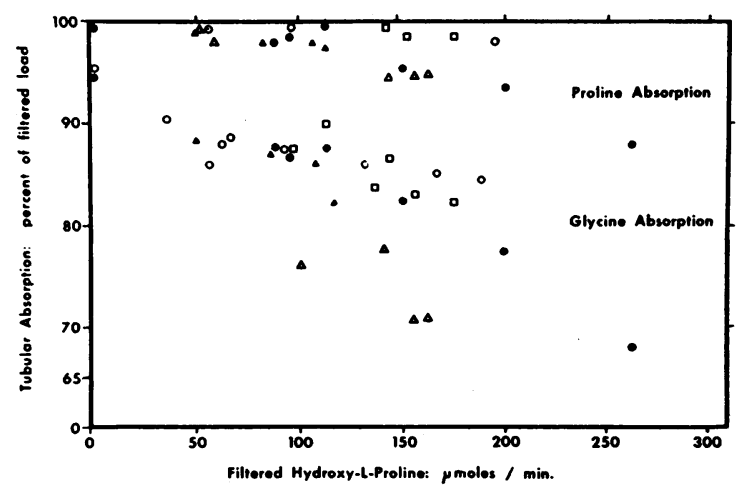

Fig. 3. INHIBITION OF tUBULAR ABSORPtion OF ENDOGENOUS GLYCINE AND PROLINE (ORDINATE) (EXPRESSED AS PER CENT OF FILTERED LOAD ACTUALLY ABSORBED) IN THE PRESENCE OF INCREASING FILTERED LOADS OF HYDROXY-LPROLINE. Symbols used as in Figure 2. greater inhibition of glycine and proline transport (Figure 3) when compared with the other two subjects with higher Tm; data at similar filtered loads of hydroxyproline were used for the comparisons.

\section{Discussion}

Free hydroxy-L-proline is transported by a system exhibiting Michaelis-Menten kinetics in vitro (4). Therefore, one expects to observe saturation of the transport system in the presence of increasing substrate concentration. This characteristic was evident in man in vivo. As the concentration of hydroxyproline was increased in the glomerular filtrate, net absorptive transport was observed to reach a maximal rate $(\mathrm{Tm})$, which was maintained over a wide range of substrate concentrations (filtered to absorbed ratio 1.4 to 4.4 ). 
TABLE IV

Inhibition of tubular transport of $\mathrm{L}$-proline by hydroxy-L-proline in man

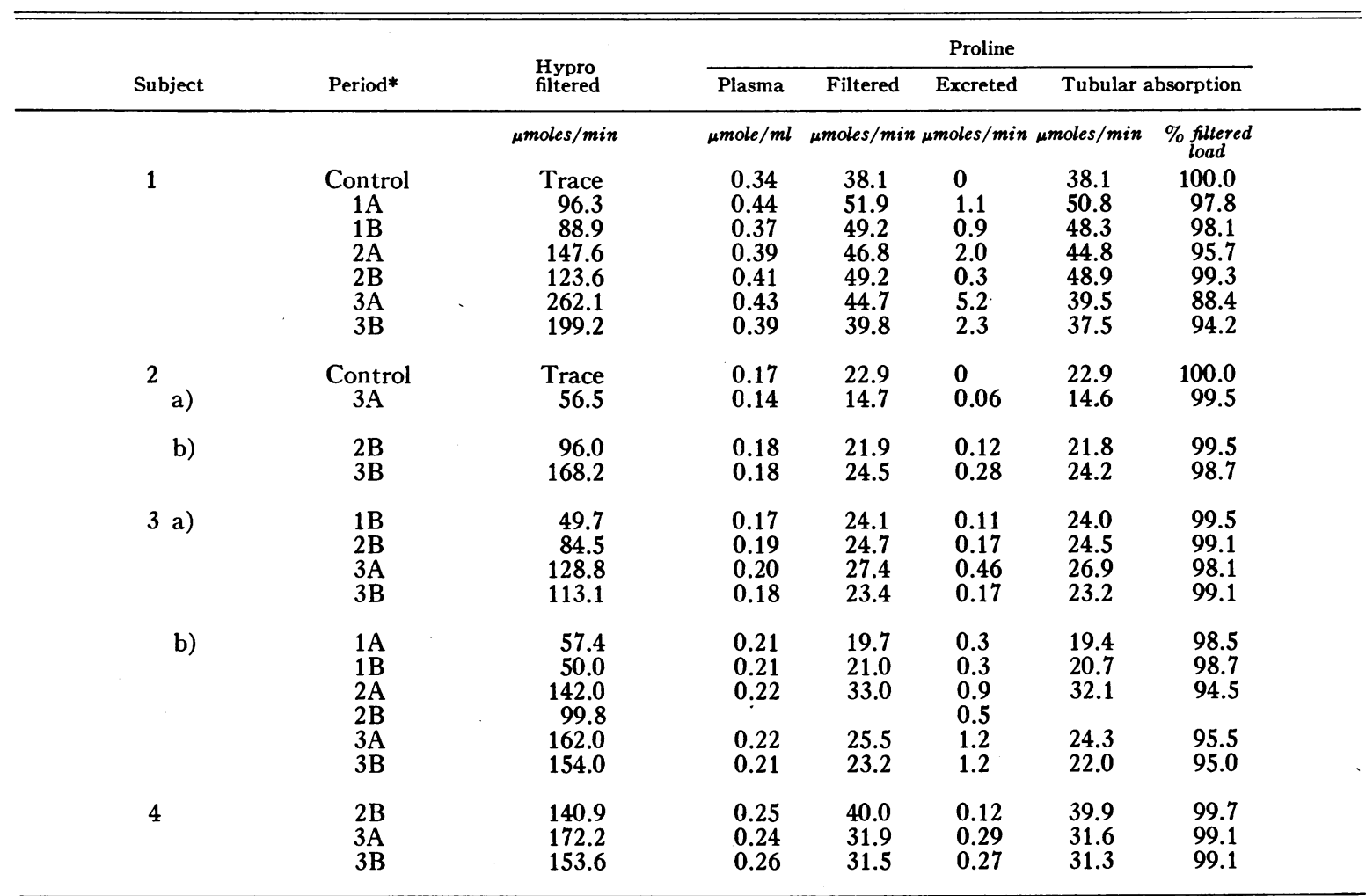

* Levels at which proline absorption was inhibited or the highest level was achieved in the study (regardless of effect) are shown. Periods of protocols not represented indicate that proline did not inhibit proline transport.

The absolute $\mathrm{Tm}$ value showed interindividual variation (Table II). This is not necessarily a technical artifact. Interindividual variation is recorded for tubular transport of proline (1) and glucose (11) in man. It has also been documented in vitro in the hamster for intestinal transport of neutral amino acids (12). Interindividual variation in transport kinetics is probably still another manifestation of biological individuality.

The $\mathrm{Tm}$ values for free hydroxy-L-proline are lower than those for free L-proline (Table V). One expects the reverse if hydroxyproline, as proposed earlier (1), has lower preference for transport than L-proline, since lower capacity or rate of substrate transport ( $\mathrm{Tm}$ or $\mathrm{V}_{\max }$ value) is usually associated with a higher affinity for the system (13). This customary relationship was observed in vitro in the rat (4). The apparent discrepancy between anticipated affinity and observed $\mathrm{Tm}$ values for L-proline and hydroxy-Lproline in vivo in man probably reflects differ- ences in the rates at which the kidney can not only absorb the two imino acids but also metabolize them. Estimates of net absorptive transport are still only summaries of a series of multicompartmental phenomena ultimately determining the relative rates at which the two substrates can leave the lumen of the renal tubule.

\section{TABLE V}

Comparative tubular transport of L-proline and hydroxy-Lproline in adult human males

\begin{tabular}{|c|c|c|}
\hline - & L-Proline* & $\underset{\text { proline }}{\text { Hydroxy-L- }}$ \\
\hline Number of subjects & 4 & 4 \\
\hline $\mathrm{Tm}, \mu$ moles $/ \mathrm{min}$ & $170-260$ & $60-135$ \\
\hline $\begin{array}{l}\text { Venous plasma threshold for } \\
\text { iminoaciduria }\end{array}$ & $>1.0$ & $0.4-0.7$ \\
\hline \multicolumn{3}{|l|}{ Per cent inhibition of glycine transport } \\
\hline $\begin{array}{l}\text { 1) at } 100 \mu \text { moles per minute filtered } \\
\text { load of inhibitor }\end{array}$ & $7-18$ & $8-21$ \\
\hline $\begin{array}{l}\text { 2) at } 200 \mu \text { moles per minute filtered } \\
\text { load of inhibitor }\end{array}$ & $10-23$ & $13-26$ \\
\hline
\end{tabular}

* Data taken or recalculated from previous work (1). 
Although the relative affinities for transport of the two imino acids cannot be deduced from Tm data, other means of evaluating this feature are available. The plasma venous threshold for appearance of iminoaciduria reflects to some extent the avidity of the transport system for the substrate; the threshold value is lower for hydroxyproline, suggesting less avid transport, when compared to the value for L-proline (Table V).

The relative affinities of the imino acids for transport might also be deduced by observing their relative efficiency as competitive inhibitors of transport of a third compound transported within the particular system. This argument is valid, however, only if all three compounds are transported at the same site, and there is evidence that this is not the case for imino acids and glycine $(4,6)$. In the present study there is some indication that hydroxyproline is a more effective competitor than proline for the glycine site (Table V). This observation was also made in vitro in rat kidney cortex slices (4). Either imino acid is a more effective inhibitor of glycine transport than of the uptake of the other imino acid. One can conclude, therefore, that either as inhibitor or substrate, imino acids have better affinity for transport than glycine.

Recently there appeared a report of a new aminoacidopathy, hydroxyprolinemia (14). Combined aminoaciduria (hydroxyproline, proline, and glycine) would be expected in this disease. Only hydroxyprolinuria was observed, in contrast to the "combined" aminoaciduria observed in hyperprolinemia $(1,2)$. The explanation for the absence of combined aminoaciduria in hydroxyprolinemia is now apparent. Competition within the tubular transport system does not usually appear until the plasma level of hydroxyproline is greater than 0.35 $\mu$ mole per $\mathrm{ml}$. When this level is reached, inhibition of glycine transport begins (Table III), but proline transport is still not significantly inhibited (Table IV). In the hydroxyprolinemic patient, the plasma level was no greater than 0.34 $\mu$ mole per ml, which is a level just sufficiently elevated to produce competition for transport in our own studies. By contrast, the plasma proline level in hyperprolinemic patients is nearly always elevated to the level where competitive inhibition within the system occurs $(1,2)$. Therefore, the combined aminoaciduria is usually found in that disease.

The present study confirms and extends our earlier investigations which indicated that amino acid transport systems in the human renal tubule exhibit the properties of saturability and substrate specificity (1). The presence of a limited number of specific membrane transport processes, a feature common to other cellular catalytic processes, is also implied by these investigations. These deductions with regard to transport processes are not new (15), but it is of interest that they can also be derived in vivo in man.

\section{Summary}

Hydroxy-L-proline was infused into four adult male subjects. Net renal tubular absorption was measured by conventional techniques involving calculation of inulin clearances and determination of amino acids in plasma and urine by elution chromatography on ion exchange resin.

A maximal rate for tubular absorption $(\mathrm{Tm})$ of free hydroxy-L-proline was observed unequivocally in two subjects and possibly also in the other two persons. The $\mathrm{Tm}$ values ranged from 60 to $125 \mu$ moles per minute.

Hydroxy-L-proline is a specific inhibitor of tubular transport of L-proline and glycine; glycine transport is inhibited more than L-proline transport. The two imino acids have higher affinity than glycine for transport in the system exhibiting preference for these three neutral amino acids.

\section{Acknowledgments}

We are indebted to Miss Sandra Pilkington, R.N., for assistance with the infusions; to Miss E. Davies, A.I.S.T., for the inulin determinations; and to Dr. Onslow Wilson for helpful discussion.

\section{References}

1. Scriver, C. R., M. L. Efron, and I. A. Schafer. Renal tubular transport of proline, hydroxyproline, and glycine in health and in familial hyperprolinemia. J. clin. Invest. 1964, 43, 374.

2. Schafer, I. A., C. R. Scriver, and M. L. Efron. Familial hyperprolinemia, cerebral dysfunction and renal anomalies occurring in a family with hereditary nephropathy and deafness. New Engl. J. Med. 1962, 267, 51.

3. Scriver, C. R., and O. H. Wilson. Multiple amino acid carrier systems in plasma membranes: genetic implications (abstract). J. Pediat. 1964, 65, 1105. 
4. Scriver, C. R., and O. H. Wilson. Possible locations for a common gene product in membrane transport of imino-acids and glycine. Nature (Lond.) 1964, 202, 92.

5. Evered, D. F., and H. G. Randall. A common pathway for uptake of glycine and proline in various living cells. Nature (Lond.) 1963, 197, 386.

6. Finerman, G. A. M., and L. E. Rosenberg. Amino acid transport in bone: evidence for separate transport systems for neutral amino and imino acids. J. biol. Chem. 1966, 241, 1487.

7. Smith, I. Aminoacids, amines, and related compounds in Chromatographic and Electrophoretic Techniques, I. Smith, Ed. New York, Interscience, 1960 , vol. 1, pp. 82-117.

8. Spackman, D. H., S. Moore, and W. H. Stein. Instruction Manual and Handbook for Model 120 Amino Acid Analyzer, D. H. Spackman, Ed. Palo Alto, Beckman Instruments, Spinco Division, 1960.

9. Scriver, C. R., E. Davies, and A. M. Cullen. Application of a simple micromethod to the screening of plasma for a variety of aminoacidopathies. Lancet 1964, 2, 230.

10. Schreiner, G. E. Determination of inulin by means of resorcinol. Proc. Soc. exp. Biol. (N. Y.) 1950, $74,117$.

11. Smith, H. W. Clearances involving active tubular reabsorption in The Kidney: Structure and Function in Health and Disease. New York, Oxford, 1958 , p. 81 .

12. Matthews, D. M., and L. Laster. Kinetics of intestinal active transport of five neutral amino acids. Amer. J. Physiol. 1965, 208, 593.

13. Lin, E. C. C., H. Hagihira, and T. H. Wilson. Specificity of the transport system for neutral amino acids in the hamster intestine. Amer. J. Physiol. 1962, 202, 919.

14. Efron, M. L., E. M. Bixby, L. G. Pallatao, and C. V. Pryles. Hydroxyprolinemia associated with mental deficiency. New Engl. J. Med. 1962, 267, 1193.

15. Christensen, H. N. Reactive sites and biological transport. Advanc. Protein Chem. 1960, 15, 239. 